This document was prepared in conjunction with work accomplished under Contract No. DE-AC09-96SR18500 with the U. S. Department of Energy.

\title{
DISCLAIMER
}

This report was prepared as an account of work sponsored by an agency of the United States Government. Neither the United States Government nor any agency thereof, nor any of their employees, nor any of their contractors, subcontractors or their employees, makes any warranty, express or implied, or assumes any legal liability or responsibility for the accuracy, completeness, or any third party's use or the results of such use of any information, apparatus, product, or process disclosed, or represents that its use would not infringe privately owned rights. Reference herein to any specific commercial product, process, or service by trade name, trademark, manufacturer, or otherwise, does not necessarily constitute or imply its endorsement, recommendation, or favoring by the United States Government or any agency thereof or its contractors or subcontractors. The views and opinions of authors expressed herein do not necessarily state or reflect those of the United States Government or any agency thereof. 


\title{
Cyclic Polarization Behavior of ASTM A537-Cl.1 Steel in the Vapor Space above Simulated Waste
}

\author{
K. H. Subramanian
}

\section{J.I. Mickalonis}

Savannah River Technology Center Strategic Materials Technology Department

Materials Technology Section

Publication Date: November 2004

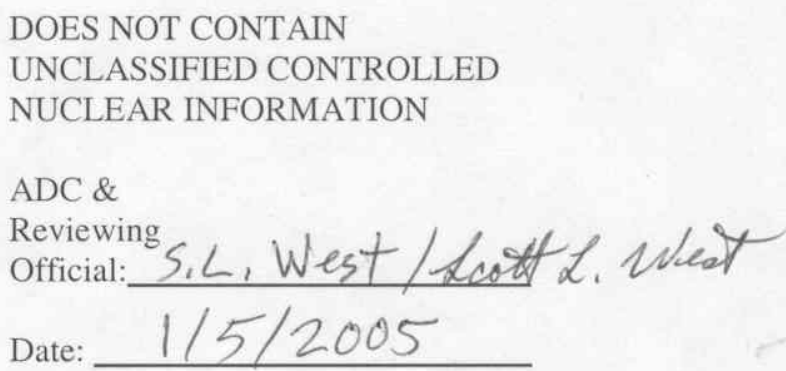

Westinghouse Savannah River Company Savannah River Site Aiken, SC 29808

This document was prepared in connection with work done under Contract No. DE-AC09-96SR18500 with the U. S. Department of Energy 
WSRC-TR-2004-00591

\section{DISCLAIMER}

This report was prepared as an account of work sponsored by an agency of the United States Government. Neither the United States Government nor any agency thereof, nor any of their employees, makes any warranty, express or implied, or assumes any legal liability or responsibility for the accuracy, completeness, or usefulness of any information, apparatus, product, or process disclosed, or represents that its use would not infringe privately owned rights. Reference herein to any specific commercial product, process, or service by trade name, trademark, manufacturer, or otherwise does not necessarily constitute or imply its endorsement, recommendation, or favoring by the United States Government or any agency thereof. The views and opinions of authors expressed herein do not necessarily state or reflect those of the United States Government or any agency thereof. 
DOCUMENT:

TITLE:
WSRC-TR-2004-00591

Cyclic Polarization Behavior of ASTM A537-Cl.1 Steel in the Vapor Space above Simulated Waste

\section{APPROVALS}

Herthis luki

K. H. Subramanian, Author

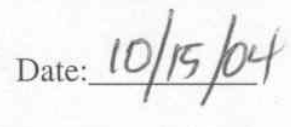

Materials Performance and Corrosion Technology

Materials Technology Section

Inattid hat for 3.1. Mickabers Date: 10/15/04

J. I. Mickalonis, Author

Materials Performance and Corrosion Technology

Materials Technology Section

Bue / Harems Date: 10/2i/04

B. J. Wiorsma, Technical Reviewer

Materials Performance and Corrosion Technology

Materials Technology Section

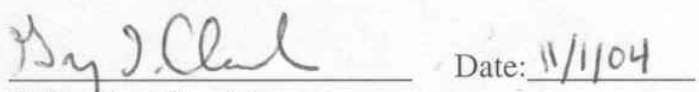

G. T. Chandler, Manager

Materials Performance and Corrosion Technology

Materials Technology Section

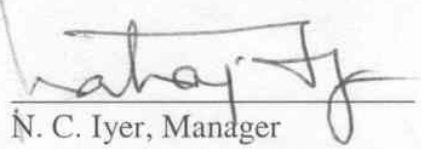

Date: $11 \mid 1104$

Materials Technology Section

Savannah River Technology Center

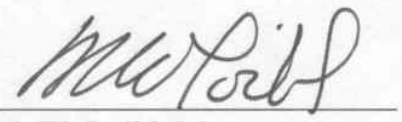

Date: $12 / 15 / 04$

M. W. Loibl, Manager

Program Engineering

Liquid Waste Disposition Project 


\section{$\underline{\text { Table of Contents }}$}

1 INTRODUCTION

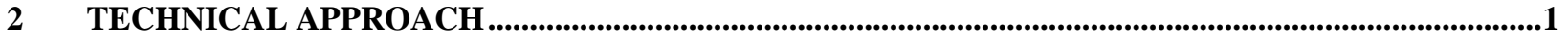

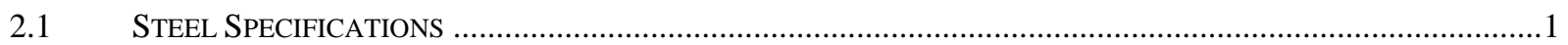

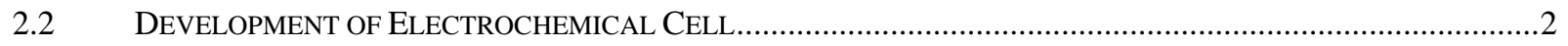

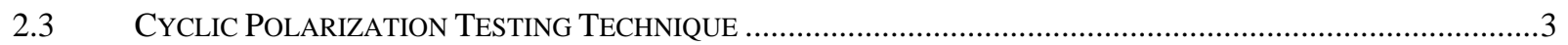

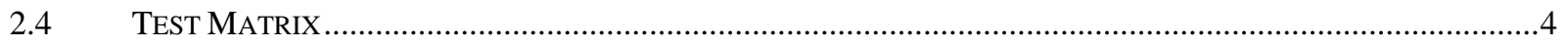

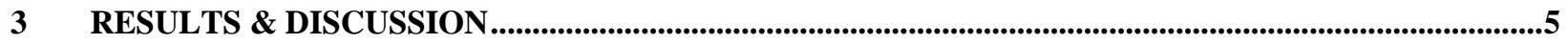

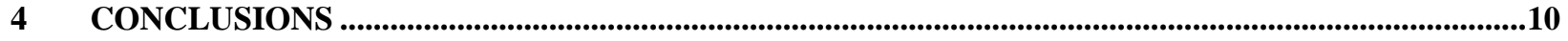

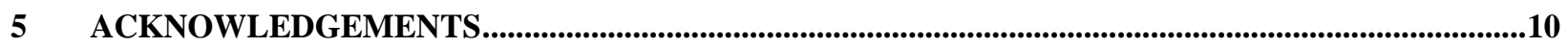

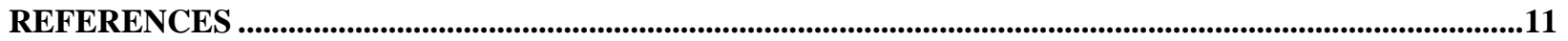




\section{$\underline{\text { List of Tables }}$}

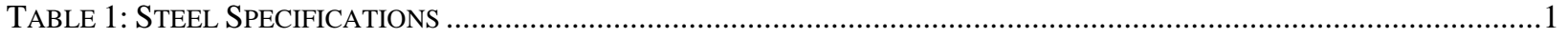

TABLE 2: TEST MATRIX FOR CYCLIC POLARIZATION TESTING.................................................................................

TABle 3: Key Characteristics of CyClic Polarization SCANS Performed AbOVE 5M NANO 3 SOlution ........6

TABle 4: Key Characteristics of CyClic Polarization Scans Performed AbOVe 3M NAOH Solution..........7

\section{List of Figures}

FIGURE 1: MiCROSTRUCTURE OF ASTM A537 CL.1 STEEL. ................................................................................

FIGURE 3: PROBE USED FOR ELECTROCHEMICAL TESTING ..............................................................................

FIGURE 4: SCHEMATIC OF CYCLIC POLARIZATION SCAN..........................................................................................

FiguRE 5: CyCliC PolariZATION SCANS PERFORMED ABOVE 5M NANO 3 SOLUTION. ...............................................5

FiguRE 6: CyCliC PolARIZATION SCANS PERFORMED ABOVE 3M NAOH SOLUTION..................................................6

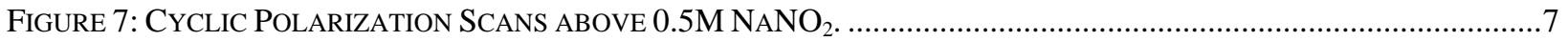

FiguRE 8: CyCLIC POLARIZATION SCANS ABOVE 1M NANO 3 /3M NAOH SOLUTION ...............................................8

FiguRE 9: CyCliC PolARIZATION SCANS ABOVE 5M NANO 3 /5M NAOH SOLUTION................................................9

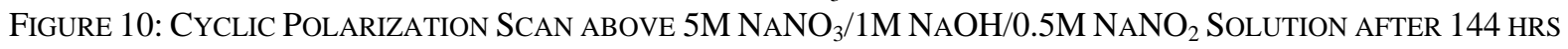

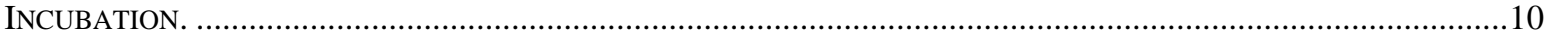




\section{INTRODUCTION}

An assessment of the potential degradation mechanisms of Types I and II High-Level Waste (HLW) Tanks determined that pitting corrosion and stress corrosion cracking were the two most significant degradation mechanisms. Specifically, nitrate induced stress corrosion cracking was determined to be the principal degradation mechanism for the primary tank steel of non-stress relieved tanks. ${ }^{1,2}$ Controls on the solution chemistry have been in place to preclude the initiation and propagation of degradation in the tanks. ${ }^{3}$ However, recent experience has shown that steel not in contact with the bulk waste solution or slurry, but exposed to the "vapor space" above the bulk waste, may be vulnerable to the initiation and propagation of degradation, including pitting and stress corrosion cracking.

A program to resolve the issues associated with potential vapor space corrosion is in place. The objective of the program is to develop understanding of vapor space (VSC) and liquid/air interface (LAIC) corrosion to ensure a defensible technical basis to provide accurate corrosion evaluations with regard to vapor space and liquid/air interface corrosion (similar to current evaluations). There are several needs for a technically defensible basis with sufficient understanding to perform these evaluations. These include understanding of the (1) surface chemistry evolution, (2) corrosion response through coupon testing, and (3) mechanistic understanding through electrochemical studies.

Experimentation performed in FY02 determined the potential for vapor space and liquid/air interface corrosion of ASTM A285-70 and ASTM A537-Cl.1 steels. The material surface characteristics, i.e. mill-scale, polished, were found to play a key role in the pitting response. The experimentation indicated that the potential for limited vapor space and liquid/air interface pitting exists at $1.5 \mathrm{M}$ nitrate solution when using chemistry controls designed to prevent stress corrosion cracking.

Experimentation performed in FY03 quantified pitting rates as a function of material surface characteristics, including mill-scale and defects within the mill-scale. Testing was performed on ASTM A537-Cl.1 (normalized) steel, the material of construction of the Type III HLW tanks. The pitting rates were approximately 3 mpy for exposure above inhibited solutions, as calculated from the limited exposure times. This translates to a penetration time of 166 years for a 0.5 -in tank wall provided that the pitting rate remains constant and the bulk solution chemistry is maintained within the L3 limit.

The FY04 testing consisted of electrochemical testing to potentially lend insight into the surface chemistry and further understand the corrosion mechanism in the vapor space. Electrochemical testing lends insight into the corrosion processes through the determination of current potential relationships. The results of the electrochemical testing performed during FY04 are presented here.

\section{TECHNICAL APPROACH}

Electrochemical testing was performed on ASTM A537-Cl.1 (normalized) steel, the material of construction of the Type III HLW tanks. A unique three electrode cell was developed for testing in the vapor space. The cyclic polarization technique was used to run experiments on variable solution chemistries. The testing was done at a bulk solution temperature of $50^{\circ} \mathrm{C}$, representative of the typical waste tank, and to reconcile with the pitting results. The details of the steel, test technique, and test matrix are presented in this section.

\subsection{Steel Specifications}

The tanks were fabricated with semi-killed, hot-rolled A537-Cl.1 plate, with nominal composition shown in Table 1. The A537 steel is a ferritic/pearlitic steel with the microstructure shown in Figure 1.

Table 1: Steel Specifications

\begin{tabular}{|c|c|c|c|c|}
\hline Steel Specification & $\mathrm{C}_{\max }(\mathrm{wt} \%)$ & $\mathrm{Mn}(\mathrm{wt} \%)$ & $\mathrm{P}_{\max }(\mathrm{wt} \%)$ & $\mathrm{S}_{\max }(\mathrm{wt} \%)$ \\
\hline ASTM A537 & 0.24 & $0.7-1.35$ & 0.035 & 0.035 \\
\hline
\end{tabular}


WSRC-TR-2004-00591

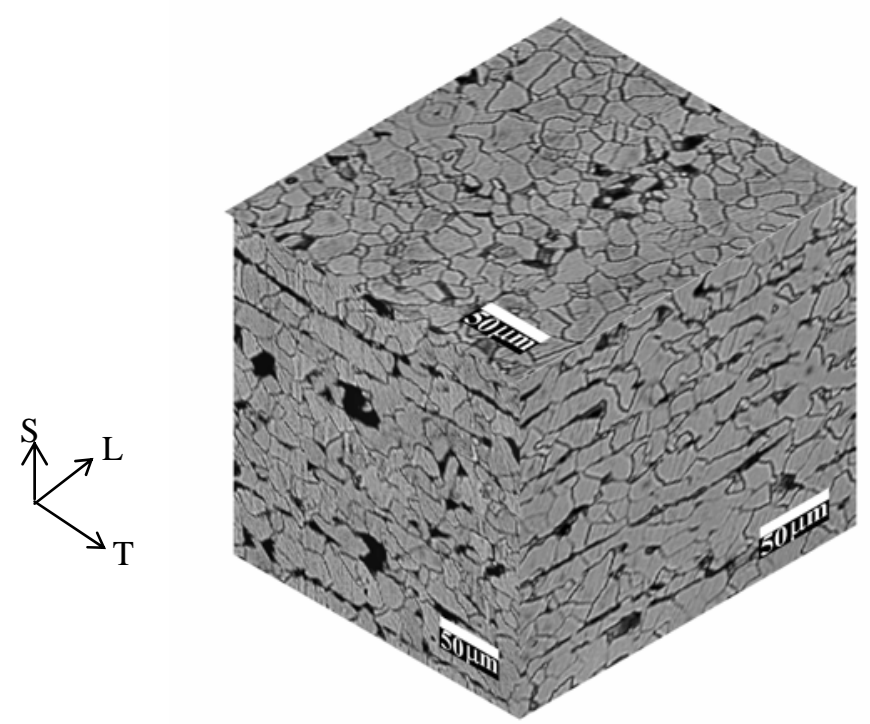

Figure 1: Microstructure of ASTM A537 Cl.1 Steel.

\subsection{Development of Electrochemical Cell}

A three electrode cell for electrochemical testing consists of a working electrode (WE), a counter electrode (CE), and a reference electrode (RE). The WE is the material for corrosion testing. The CE conducts the generated current during a controlled-potential test. The WE potential is measured relative to the RE potential, which must maintain a constant potential for the exposure conditions. To conduct electrochemical testing with the probe, a continuous conductive path is necessary between all three electrodes. A thin film is formed on the surface of the entire mount through condensation over a heated solution of simulated high level waste. The setup is schematically shown in Figure 2.

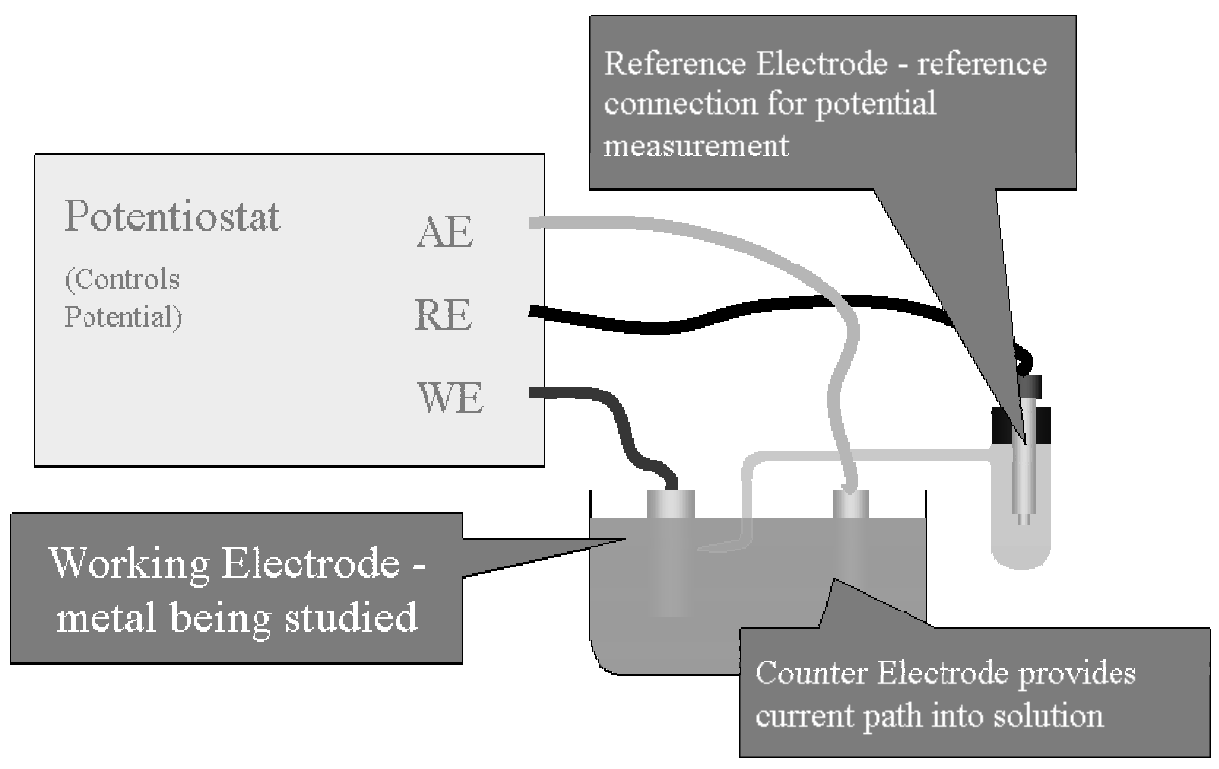

Figure 2: Schematic of Three Electrode Electrochemical Test Setup 
A unique probe was developed to perform electrochemical experimentation in the vapor space. The three-electrode probe consisted of a carbon steel working electrode, a SS 304-L counter electrode, and a Pt-wire reference electrode. The electrodes were embedded in a metallurgical mount useable in the vapor space for testing. For this probe, the WE is ASTM A537-Cl.1 steel, the CE is 304L stainless steel, and the RE is the platinum wire. The probe is shown is shown in Figure 3.

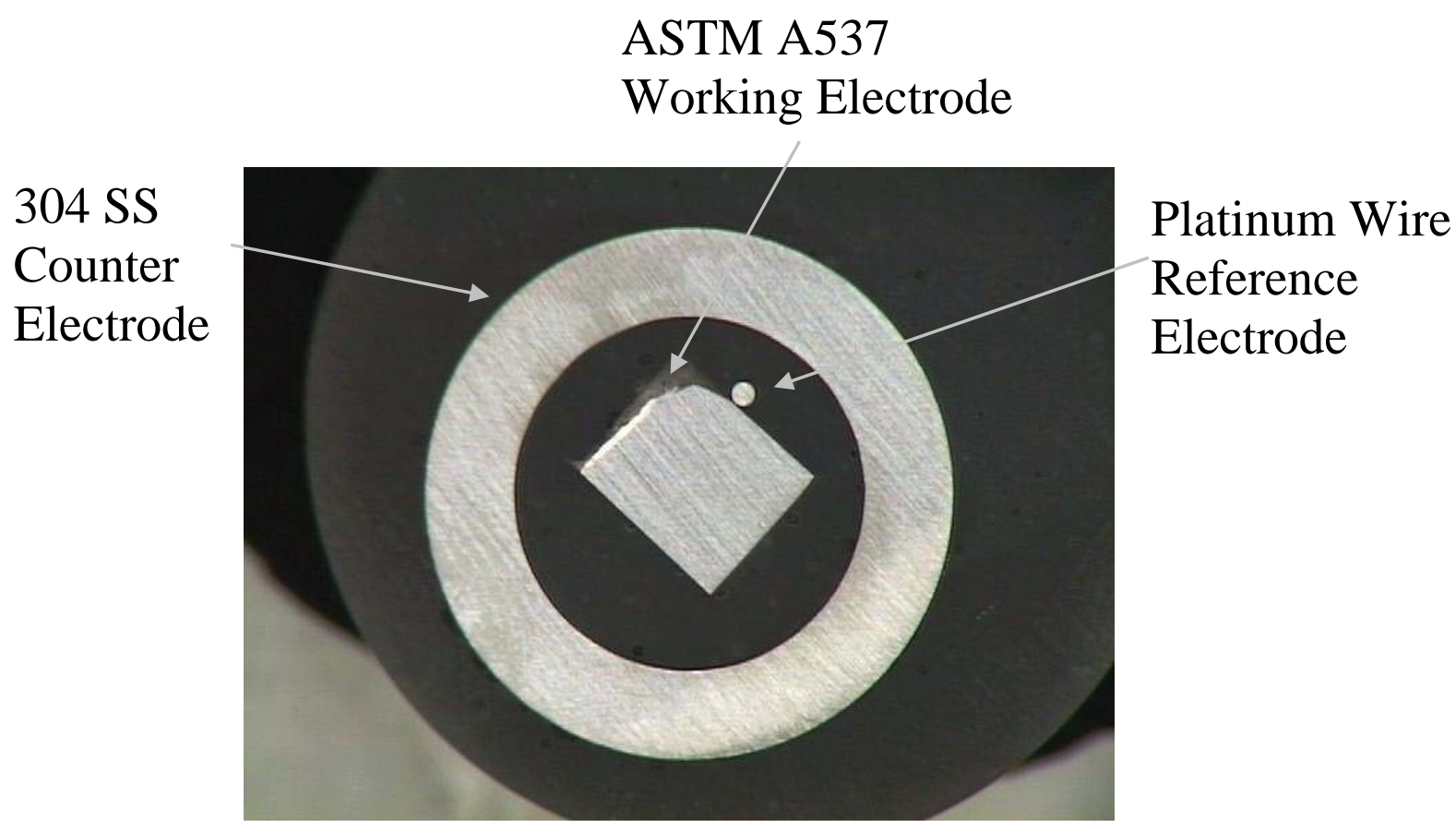

Figure 3: Probe Used for Electrochemical Testing

The function testing consisted of developing characteristic linear polarization and cyclic polarization scans utilizing typical electrochemical cells in bulk solutions and comparing them with results from the probe in the same bulk solution. Finally, LP/CP scans were done with the probe in the vapor space and compared to the bulk solution results. The probe was tested in both bulk solution and the vapor space to ensure functionality within the vapor space. Linear and cyclic polarization scans were used to determine characteristic curves in the bulk solutions and then compared results in the vapor space. The bulk solutions used were "uninhibited" $(5 \mathrm{M} \mathrm{NaNO})_{3}$ and "inhibited" $\left(1.5 \mathrm{M} \mathrm{NaNO}_{3}, 0.45 \mathrm{NaNO}_{2}, 0.15 \mathrm{NaOH}\right.$ ). The inhibited solution is in accordance with chemistry controls currently used within the high level waste tanks. The inhibited solution was in accordance with chemistry controls currently used within the high level waste tanks. The polarization scans were obtained using a computer-controlled potentiostat (EG\&G PAR Model 273A). The tests were performed in a one-liter cell. A hot plate was used to control temperature $\left( \pm 2^{\circ} \mathrm{C}\right)$. Approximately $750 \mathrm{ml}$ of solution was used for each test.

LP/CP scans were initially done in bulk solutions using the standard electrochemical setup with ASTM A537-Cl.1 WE, graphite CE, and a saturated calomel reference electrode (SCE). The scans were then performed in bulk solution with the probe and an external platinum reference. The results of the testing confirmed the functionality of the two-electrode (WE/CE) probe with an external reference. Scans performed with the two-electrode embedded cell in the vapor space yielded similar results provided that a conductive continuous thin film could be established over the surface of both electrodes.

\subsection{Cyclic Polarization Testing Technique}

Cyclic polarization scans were done to determine the susceptibility to pitting. The cyclic polarization technique is normally used to qualitatively evaluate a metal's tendency to pit in a corrosive environment. The experiment is 
based on a slow linear sweep of the potential of a metal. The initial sweep is towards anodic potentials. When the measured current reaches a specified level, the sweep direction is reversed and a cathodic going sweep occurs. The graphical output of the experiment is a plot of log current versus potential. Both forward and reverse sweeps are shown on one plot. Significant hysteresis between the sweeps is an indication of pit formation. Potential scan is applied beginning at $\mathrm{E}_{\text {corr }}$ and continued in the positive direction. The applied potential is reversed and scanned back to the corrosion potential. The scan is used to measure pitting and crevice corrosion susceptibility. It also used to characterize the stability of oxide coating and to determine the effectiveness of inhibitors.

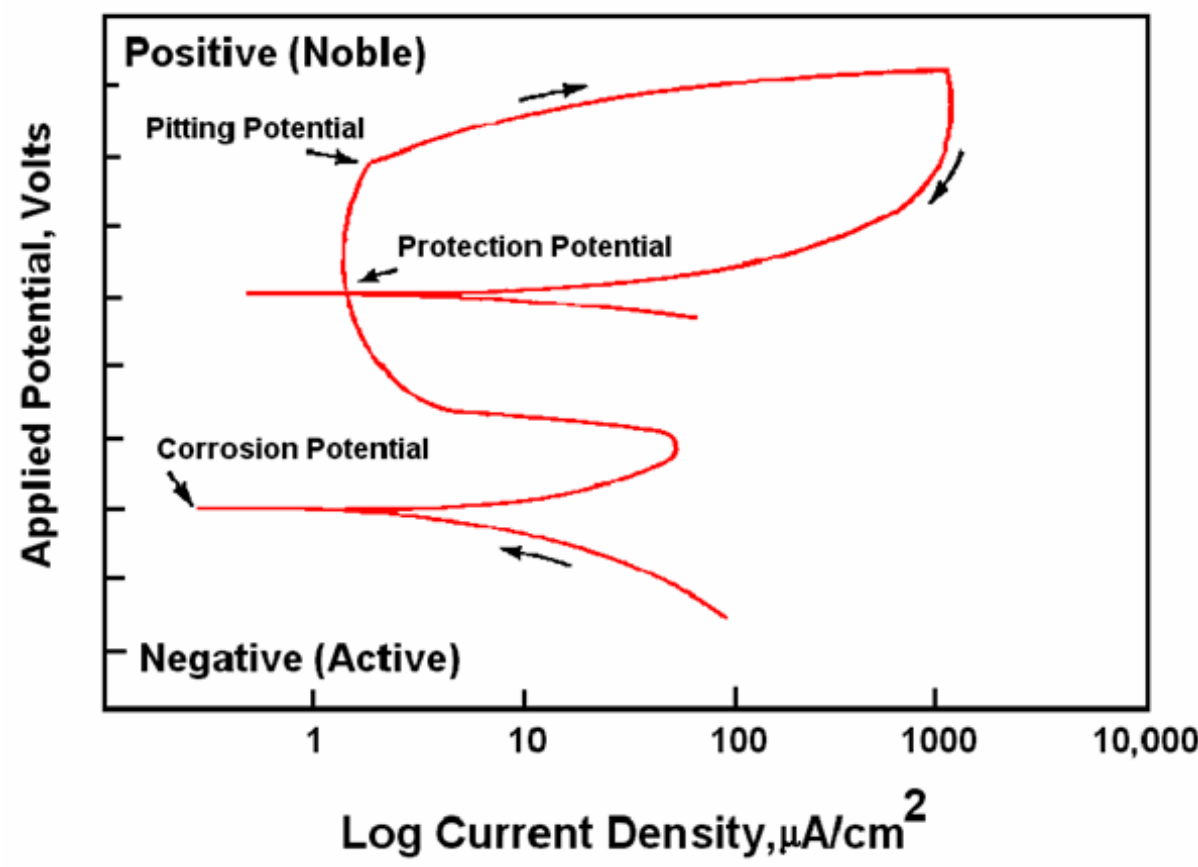

Figure 4: Schematic of Cyclic Polarization Scan

\subsection{Test Matrix}

Anodic polarization curves to determine the effect of time on the corrosion response were initially developed to determine the appropriate test matrix for $\mathrm{CP}$ testing. The testing was done with the metallurgical mount exposed to the vapor space above bulk solution with nominal composition $5 \mathrm{M} \mathrm{NaNO}_{3}, 3 \mathrm{M} \mathrm{NaOH}$, and $0.5 \mathrm{M} \mathrm{NaNO}_{2}$. The bulk solution was maintained at a temperature of $50^{\circ} \mathrm{C}$. Anodic polarization testing was initially performed immediately after exposure, i.e., once a film was visually detected across the sample surface. Testing was then performed after exposures of 24, 48, 72, and 168 hours. The samples were allowed to incubate in the test cell during the exposures. Several observations were made from the data. The open circuit potential tends to become less negative with consecutive incubations indicating a change in the electrolytic concentration of the thin film on the sample surface. Additionally, the data suggests an oxide transition at 0.1-0.6 V-SCE. Based upon the data gathered, the test matrix defined for CP testing is shown in Table 2.

Table 2: Test Matrix for Cyclic Polarization Testing

\begin{tabular}{|c|c|c|c|}
\hline Solution \# & NaNO3 & NaOH & NaNO2 \\
\hline 1 & $5 \mathrm{M}$ & & \\
\hline 2 & & $3 \mathrm{M}$ & \\
\hline 3 & & & $0.5 \mathrm{M}$ \\
\hline 4 & $5 \mathrm{M}$ & $1 \mathrm{M}$ & \\
\hline 5 & $1 \mathrm{M}$ & $3 \mathrm{M}$ & \\
\hline
\end{tabular}




\begin{tabular}{|c|c|c|c|}
\hline Solution \# & NaNO3 & NaOH & NaNO2 \\
\hline 6 & $5 \mathrm{M}$ & $3 \mathrm{M}$ & $0.5 \mathrm{M}$ \\
\hline
\end{tabular}

*Incubation times of 72, 144, and 216 hours were tested

\section{RESULTS \& DISCUSSION}

The results for each of the solutions are shown in Figure 5-Figure 10. The data has been refined to provide the best possible representation. However, due to the transient nature and the minimal thickness of the thin film, the data has a significant amount of noise. Nevertheless, key points as to the presence of the hysteresis loop and potential for pitting can be inferred. The key characteristics of the CP scan are summarized in Tables following the figures. The corrosion potential ( $\mathrm{E}_{\text {corr }}$, pitting potential, and protection potential are reported in the presence of a hysteresis loop.

The cyclic polarization scans performed above 5M NaNO3 solution are shown in Figure 5. It is seen that the hysteresis loop was present initially, but disappears with additional incubation time.

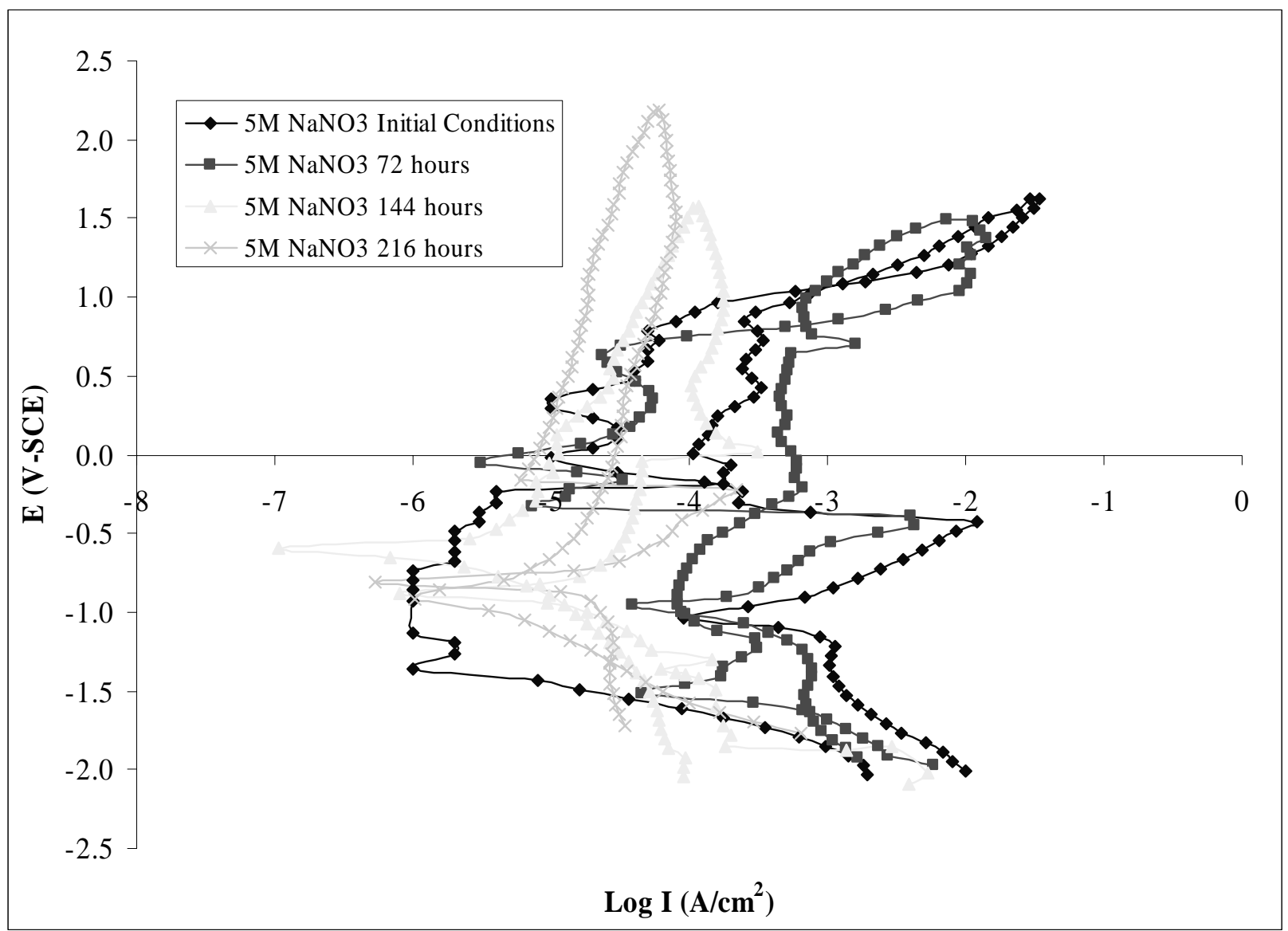

Figure 5: Cyclic Polarization Scans Performed Above 5M NaNO 3 Solution.

The key characteristics are shown in Table 3. It is seen that that the initial pitting potential is 0.9V-SCE that is driven to $1.54 \mathrm{~V}$-SCE given time to passivate the surface. The current densities decrease with time indicating the higher stability of the passive oxide film, and hence better protection against pitting. Pitting potentials and $\mathrm{E}_{\text {corr }}$ have been reported by Zapp and Van Zee for low carbon steel immersed in more dilute solutions of sodium nitrate. ${ }^{4}$ The $\mathrm{E}_{\text {corr }}$ data in the vapor space are in-line with extrapolation of the Zapp data. However, the pitting potentials are more noble, indicating better protection once a stable oxide film is formed. 
Table 3: Key Characteristics of Cyclic Polarization Scans Performed Above $5 \mathrm{M} \mathrm{NaNO}_{3}$ Solution

\begin{tabular}{|c|c|c|c|}
\hline Condition & Ecorr (V-SCE) & Pitting Potential (V-SCE) & Protection Potential (V-SCE) \\
\hline Initial & -1 & 0.9 & 0.9 \\
\hline $72 \mathrm{hrs}$ & -1 & 1.54 & 1.29 \\
\hline $144 \mathrm{hrs}$ & -0.4 & N/A & N/A \\
\hline $216 \mathrm{hrs}$ & -0.9 & N/A & N/A \\
\hline
\end{tabular}

In the $3 \mathrm{M} \mathrm{NaOH}$ solution, no hysteresis loops are present, but there is an increase in passive current density with incubation as shown in Figure 6. This increase in current density may be attributed to the increasing concentration of hydroxide within the thin film present on the surface. Additionally, the increased current density may be the action of the formation of the $\mathrm{Fe}_{3} \mathrm{O}_{4}$ layer on the surface with increased concentration of hydroxide.

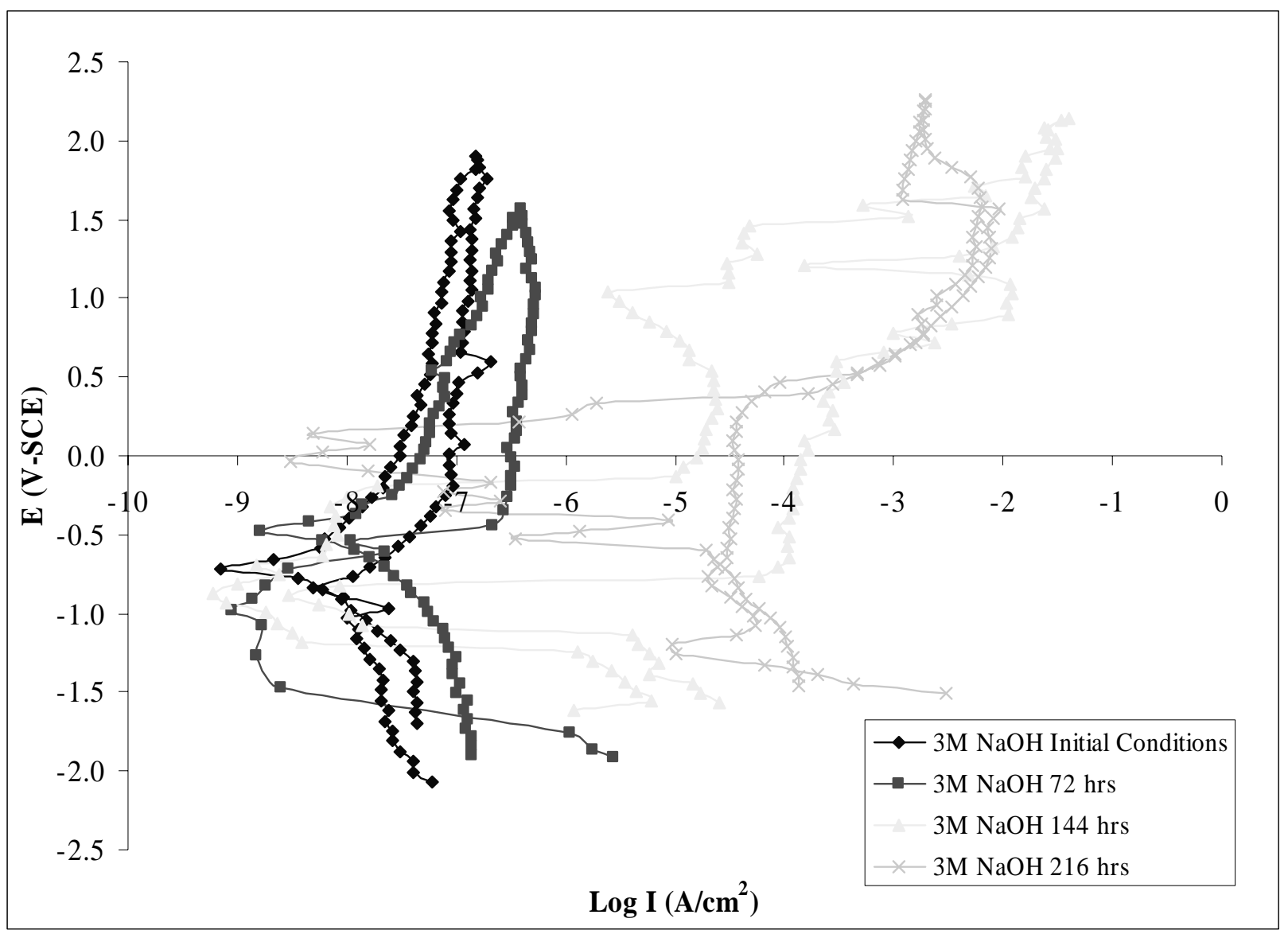

Figure 6: Cyclic Polarization Scans Performed Above 3M NaOH Solution.

The key characteristics are shown in Table 4. It is seen that that the $\mathrm{E}_{\text {Corr }}$ remains within experimental error band throughout. The $\mathrm{E}_{\text {corr }}$ values are similar to those expected when exposed to bulk solution. The $\mathrm{E}_{\text {corr }}$ does not typically change as a function of hydroxide concentration for low carbon steel. 
Table 4: Key Characteristics of Cyclic Polarization Scans Performed Above 3M NaOH Solution

\begin{tabular}{|c|c|c|c|}
\hline Condition & Ecorr (V-SCE) & Pitting Potential (V-SCE) & Protection Potential (V-SCE) \\
\hline Initial & -0.9 & N/A & N/A \\
\hline $72 \mathrm{hrs}$ & -1 & N/A & N/A \\
\hline $144 \mathrm{hrs}$ & -1 & N/A & N/A \\
\hline $216 \mathrm{hrs}$ & -1.2 & N/A & N/A \\
\hline
\end{tabular}

The cyclic polarization scans performed above $0.5 \mathrm{M} \mathrm{NaNO}_{2}$ solution are shown in Figure 7 . The scans show a very low current density and no hysteresis loop as expected.

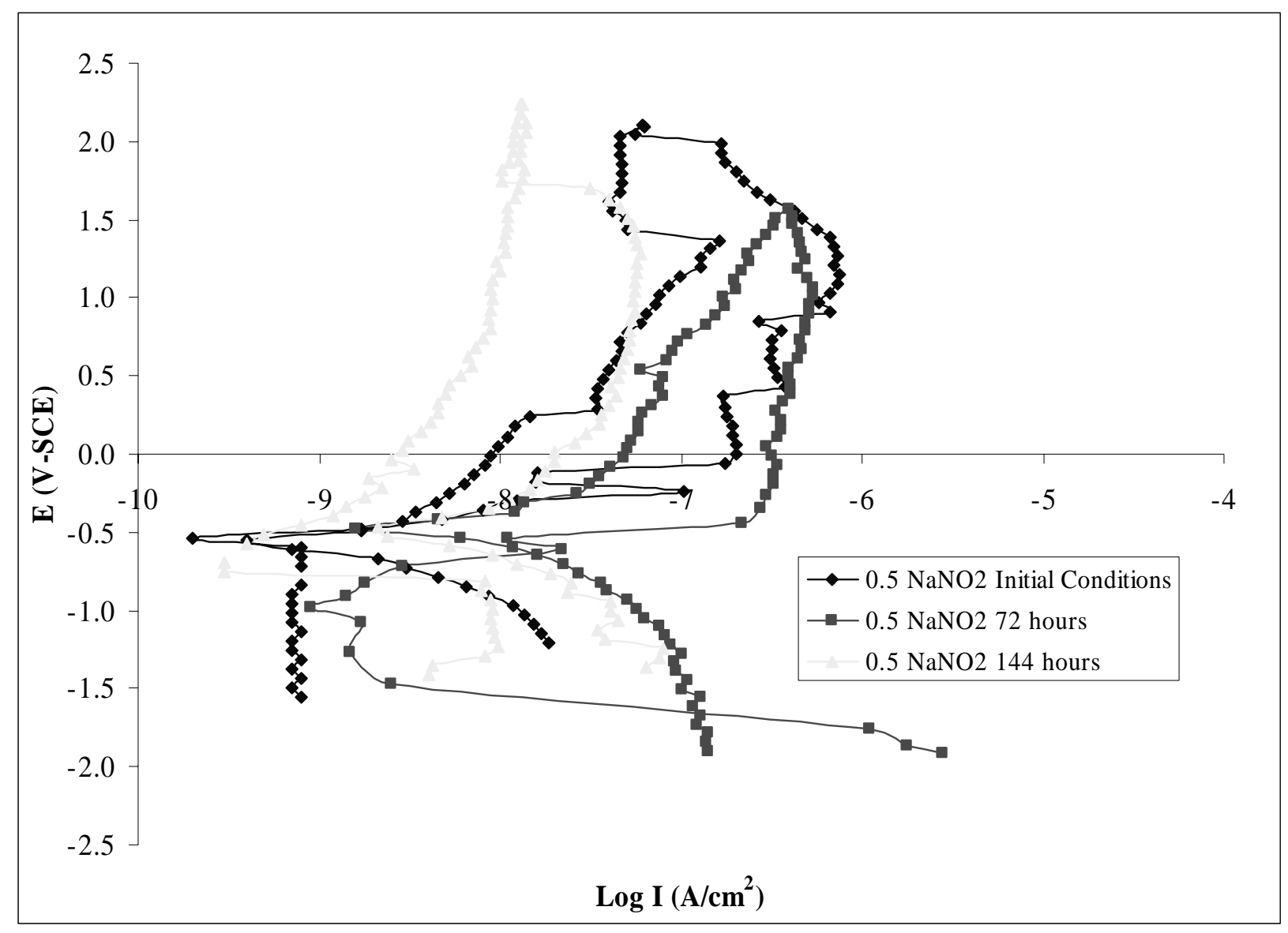

Figure 7: Cyclic Polarization Scans above 0.5M NaNO .

The cyclic polarization scans performed above $1 \mathrm{M} \mathrm{NaNO}_{3} / 3 \mathrm{M} \mathrm{NaOH}$ solution are shown in Figure 8. The scans are erratic, but do not indicate a hysteresis loop. The scans at the further incubation time were too erratic for refinement and not presented. However, visual analysis of the specimen surface indicated general edge corrosion and insignificant, shallow pitting. Pit depths were too shallow to be accurately measurable. 


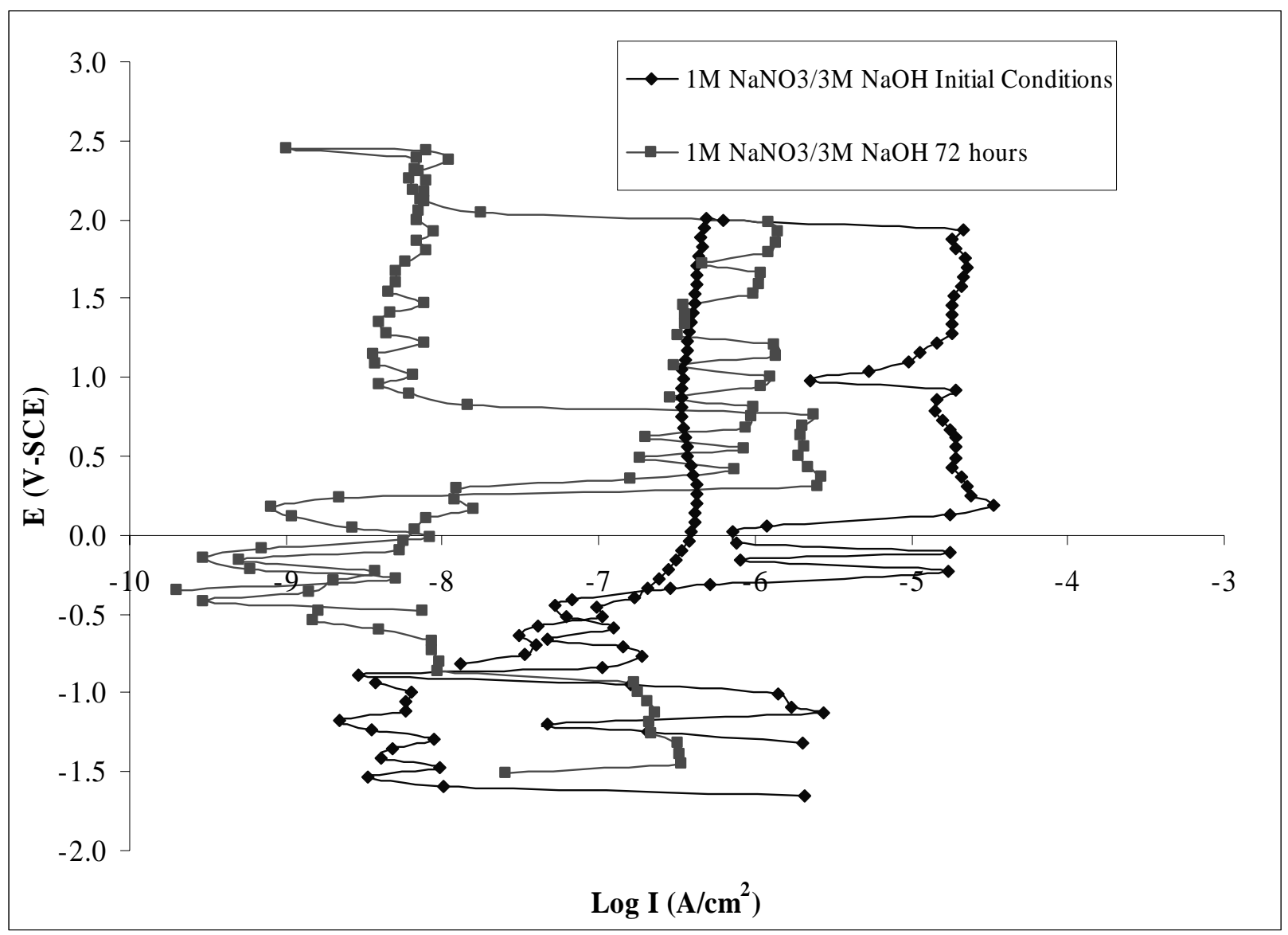

Figure 8: Cyclic Polarization Scans above $1 \mathrm{M} \mathrm{NaNO}_{3} / 3 \mathrm{M} \mathrm{NaOH}$ Solution.

The cyclic polarization scans performed above $1 \mathrm{M} \mathrm{NaNO}_{3} / 3 \mathrm{M} \mathrm{NaOH}$ solution are shown in Figure 9 . The scans are very stable and do not indicate a hysteresis loop. 


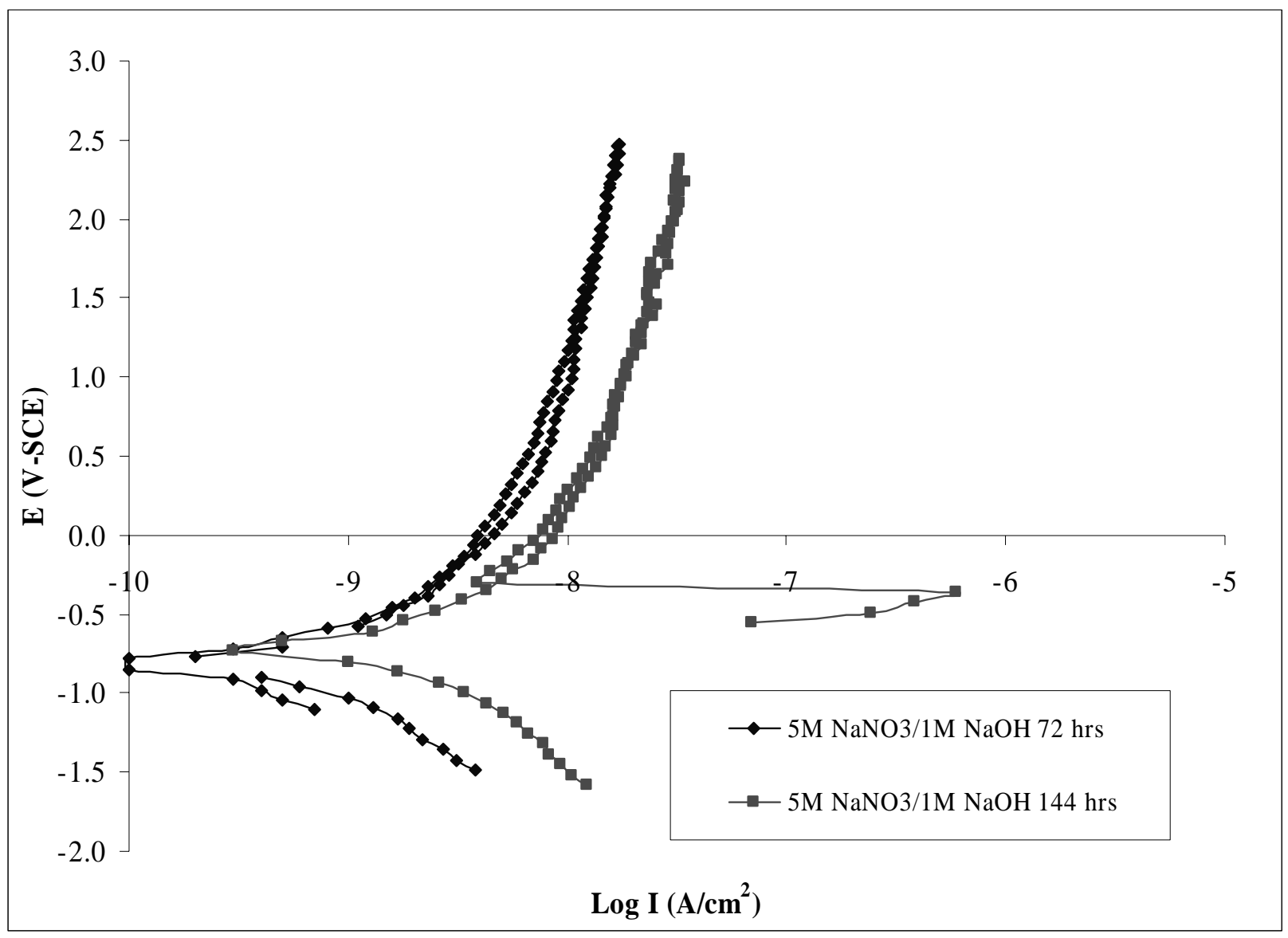

Figure 9: Cyclic Polarization Scans above $5 \mathrm{M} \mathrm{NaNO} / 5 \mathrm{M} \mathrm{NaOH}$ Solution.

The cyclic polarization scans performed above $5 \mathrm{M} \mathrm{NaNO}_{3} / 1 \mathrm{M} \mathrm{NaOH} / 0.5 \mathrm{M} \mathrm{NaNO}$ solution are shown in Figure 10. The scan is erratic and shows several instabilities, but does not indicate a hysteresis loop. Only the 144 hour incubation test result is presented here due to data refinement procedures. However, visual analysis of the samples concluded that only minor insignificant pitting was present. 


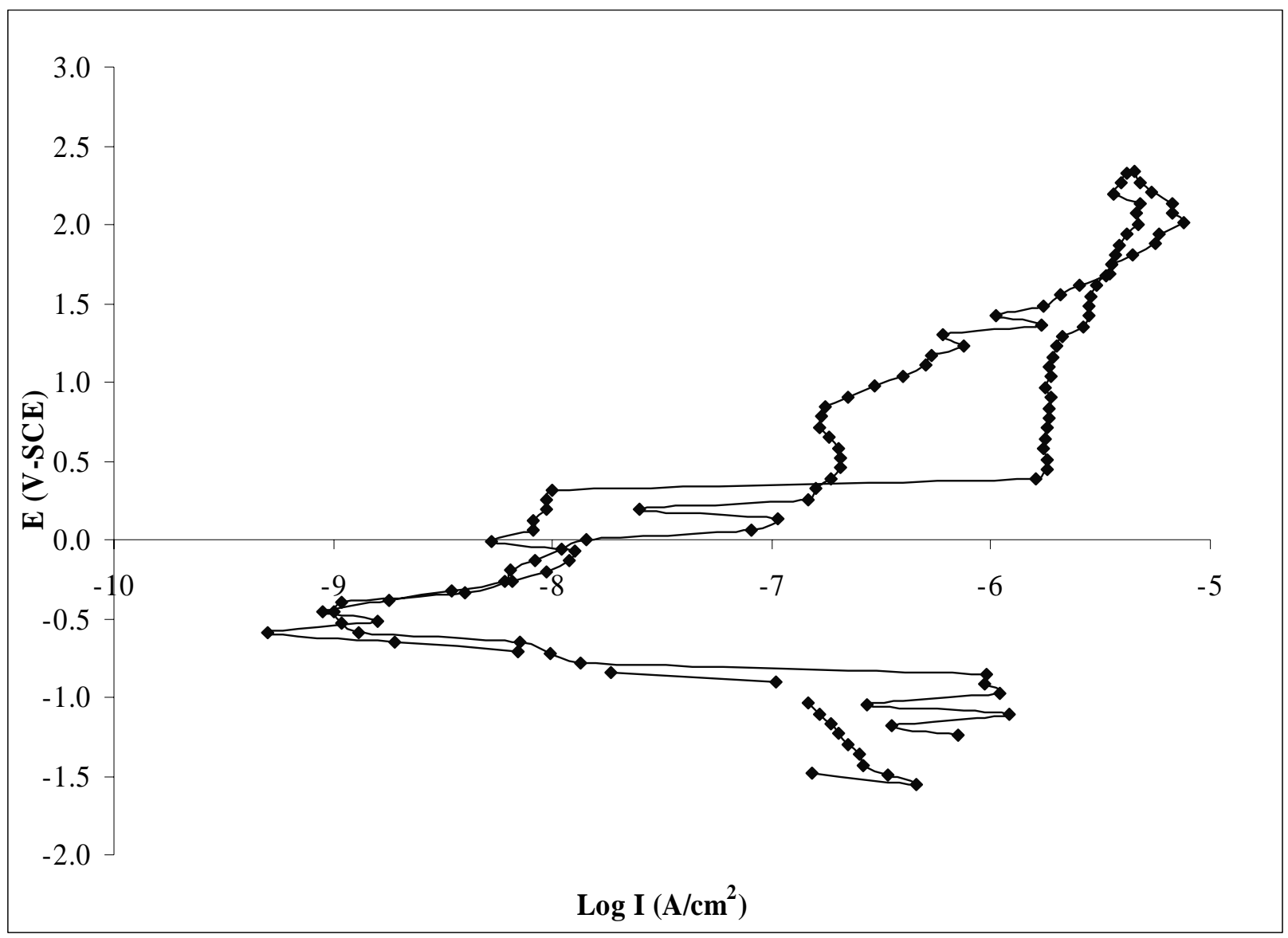

Figure 10: Cyclic Polarization Scan above $5 \mathrm{M} \mathrm{NaNO}_{3} / 1 \mathrm{M} \mathrm{NaOH} / 0.5 \mathrm{M} \mathrm{NaNO}{ }_{2}$ Solution after $144 \mathrm{hrs}$ Incubation.

\section{CONCLUSIONS}

Electrochemical testing was done in the vapor space above various waste simulants containing nitrate/nitrite/hydroxide solutions. The cyclic polarization behavior of low carbon steel in this vapor space was developed to determine the potential for pitting in the Type III Tanks. The cyclic polarization testing confirmed that pitting is electrochemically improbable in the vapor space provided the bulk solution chemistry is sufficiently inhibited, for a bulk solution temperature of $50^{\circ} \mathrm{C}$. Further coupon testing and electrochemical testing is planned in more complex solution to determine the effect of the minor constituents.

\section{ACKNOWLEDGEMENTS}

The author would like to thank Karen Hicks for technician support and performing the experiments. Additionally, the author thanks B.J. Wiersma, P.E. Zapp, and A.J. Duncan for technical assistance. 


\section{REFERENCES}

${ }^{1}$ Costas, L. P., Holzworth, M. L., Rion, W.C., "Stress Corrosion Cracking of Carbon Steels in Simulated Waste Solutions,” DP-1023, June 1966.

${ }^{2}$ Poe, W. L., “Leakage from Waste Tank 16: Amount, Fate, and Impact,” DP-1358, November 1974.

3 “TSR Administrative Control Compliance Requirements, Corrosion Control Program,” G-TRT-G-00003, Appendix 6 Rev. 7, Westinghouse Savannah River Company, Aiken, SC, June 2000.

${ }^{4}$ Zapp, P.E., Van Zee, J.W., "Mechanism of Pitting Corrosion Prevention by Nitrite in Carbon Steel Exposed to Dilute Salt,” WSRC-MS-2002-00078, March 2002. 